\title{
The Role of Endocannabinoid System in Menopause and Its Related-Diseases
}

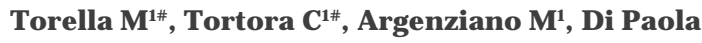
$A^{2}$, Riemma $G^{1}$, Di Leva $C^{1}$, La Verde $M^{1}$ and Rossi $\mathbf{F}^{1 *}$

${ }^{1}$ Department of Woman, Child and General and Specialist Surgery, University of Campania “Luigi Vanvitelli”, Italy ${ }^{2}$ Department of Experimental Medicine, University of Campania "Luigi Vanvitelli", Italy

"Contributed Equally to this Work

*Corresponding author: Rossi F, Department of Woman, Child and General and Special Surgery, University of Campania “Luigi Vanvitelli” Via De Crecchio, 4 - 80138 Naples, Italy

Received: March 13, 2021; Accepted: March 25, 2021; Published: April 01, 2021

\begin{abstract}
Menopause is a crucial event in women's health, characterized by the cessation of ovarian function. The estrogens deficiency exposes women to several diseases, including obesity, osteoporosis, cardiovascular diseases and cancer. Menopause-related diseases deeply impact on women's quality of life and represent a serious public and economic health burden. The Endocannabinoid System (ECS) includes Cannabinoid Type 1 (CB1) and Cannabinoid Type 2 (CB2) receptors, endocannabinoids and all the enzymes involved in their biosynthesis and degradation. It plays a significant role in energy balance, bone metabolism, muscular contractility, vascular tone and cancer progression. CB1 activation is responsible for increasing food intake and body weight, stimulating osteoclast activity, inhibiting oxidative stress and preventing cancer progression. Conversely, the stimulation of $\mathrm{CB} 2$ induces a reduction in food intake and in body weight, inhibits osteoclast activity, prevents vascular risk and reduces cancer cells proliferation. Moreover, several polymorphic variants of cannabinoid receptors genes are involved into obesity and osteoporosis.

In menopause, the alteration of cannabinoid receptors expression and endocannabinoids levels as well as their role in hormone-related pathways could act a leading role in different pathologies (obesity, osteoporosis, cardiovascular diseases and cancer). Therefore, ECS could be considered a possible prognostic marker and a therapeutic target to oppose the harmful effects of these menopause-related diseases. In this review we aimed to summarize the current state-of-knowledge concerning the impact of ECS on major health issues of postmenopausal women.
\end{abstract}

Keywords: Menopause; Endocannabinoid system; Obesity; Osteoporosis; Cardiovascular disease; Cancer

\section{Introduction}

Menopause is a crucial event of women life. The process is sustained by a significant decrease of estrogens and progesterone production by ovarian tissues due to natural depletion and aging of the oocytes [1]. Natural menopause is diagnosed after 12 months amenorrhea not related to pathologies, surgery or any kind of therapy (chemo- or radiotherapy) and in the majority of cases it occurs after the age of $51[2,3]$. Conversely, surgical menopause occurs when the cessation of ovarian function is related to surgical removal or medical conditions. Among the clinical conditions associated to early-onset menopause, premature ovarian failure is the leading cause and happens when the cessation of ovarian function happens before the age of 40 . It could be idiopathic or related to several pathologies (i.e. autoimmune disorder, diabetes mellitus, and thyroid diseases [4].

Postmenopausal women could experience several symptoms, sometimes responsible for strong life quality compromise. Although changing in intensity and frequency from a patient to patient, those symptoms include Vasomotor Symptoms (VMS), sleep disturbances, genitourinary syndrome of menopause (i.e., vulvovaginal atrophy), as well as psychologic and emotional disorders [4,5]. Moreover, the earlier is the onset of menopause the most elevated is the risk of cardiovascular diseases. Other complications especially related to reduction in estrogen levels are inflammation, immunological dysfunction, anemia, alteration in bone metabolism, cognitive disorders, alteration in RAS proteins pathway, frequently altered in cancer [6].

The Endocannabinoid System (ECS) is a complex endogenous signaling system constituted by: - two 7-transmembrane-domain and $G$ protein-coupled receptors, the Cannabinoid Receptor Type-1 (CB1) and the Cannabinoid Receptor Type-2 (CB2); their ligands (or endocannabinoids), $\mathrm{N}$-arachidonoylethanolamine or anandamide (AEA) and 2-arachidonoylglycerol (2-AG); the enzymes responsible for endocannabinoid biosynthesis, named N-Acyl Phosphatidylethanolamine-Specific Phospholipase D (NAPE-PLD) and Diacylglycerol Lipase (DAGL), and, for their inactivation, Fatty Acid Amide Hydrolase (FAAH) and Monoacylglycerol Lipase (MAGL) [7]. ECS is involved in several biological functions: appetite regulation, pain management, organism development, modulation of inflammatory processes and immune response [8]. Considering the variety of physiological functions in which it is involved and also the evidences about its dysregulation in the pathogenesis of many diseases, ECS has been often proposed as therapeutic target for several conditions, including metabolic disorders [9], osteoporosis [10], cardiovascular disease [11] and cancer [12]. Moreover, a crosstalk between ECS and sex hormones is well-documented, in particular the alteration of estrogens and progesterone production 


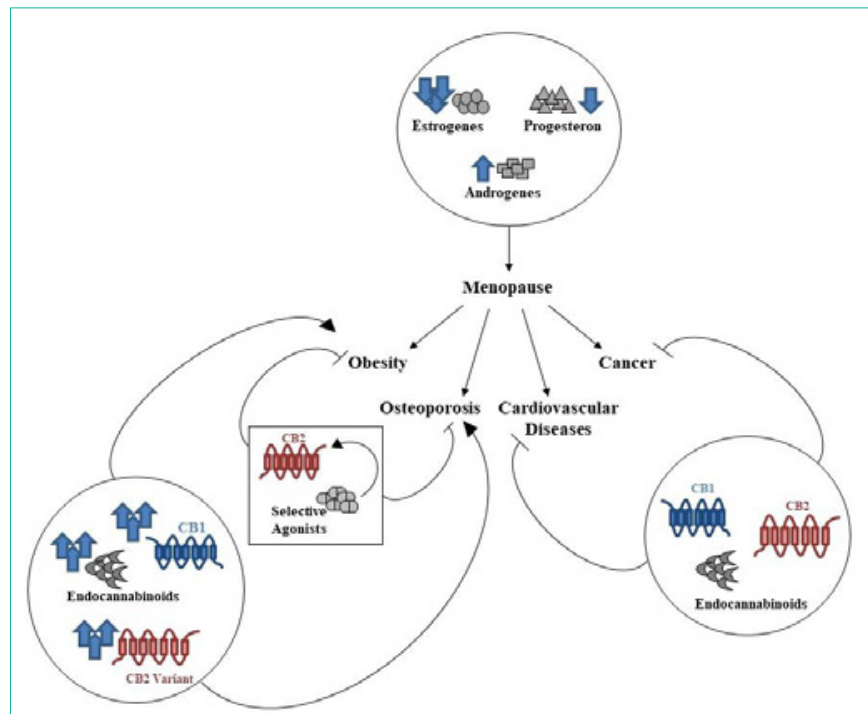

Figure 1: Crosstalk between ECS and sex hormones in menopause. Sex hormones alteration is associated to several disorders in post-menopausal women (obesity, osteoporosis, cardiovascular diseases and cancer). ECS could represent a good therapeutic target to contain the risk to develop these pathologies.

in postmenopausal women is strongly related to alteration in ECS activity (Figure 1) [13].

This review provides up-to-date insights on the role of ECS in postmenopausal women and the possibility to target it in order to oppose the harmful effects of menopause-related diseases.

\section{Obesity in Menopause: Role of Endocannabinoids System}

During menopause, the reduction of circulating estrogens and the increase of androgens play a role on the onset of metabolic syndrome, dysregulation of lipid metabolism and obesity [14], with a strong elevation of total body fat mass and fat percentage [15-17]. Since androgen and estrogen receptors are expressed in visceral and subcutaneous adipocytes, changes in these hormones levels induce an accumulation of visceral abdominal fat [18]. This accumulation determines alterations in fatty acid metabolism, causing a significant lipolysis which results in an increased Free Fatty Acids (FFAs) translocation in the liver, development of hyperinsulinemia and hepatic insulin resistance responsible of for dyslipidemia, obesity, metabolic syndrome and type 2 diabetes $[14,19]$. In particular, in postmenopausal women the Adipose Tissue Lipoprotein Lipase (ATLPL) is more active than in premenopausal women, determining an increase of FFAs synthesis in gluteal and abdominal adipose tissue [20]. Furthermore, postmenopausal women also show a reduction of Fat-Free Mass (FFM) which led to a reduction of Basal Metabolic Rate (BMR), the energy necessary for the maintenance of biological functions, decreasing energy expenditure and altering energy metabolism [17,21]. Estrogens reduction and deregulation of lipid metabolism predispose postmenopausal women to Cardiovascular Diseases (CVDs) [22]. Indeed, in menopause it is reported an increase of total cholesterol, triglycerides, Low Density Lipoprotein (LDL) levels and of total cholesterol/High Density Lipoprotein (HDL) ratio, which lead to CVDs [23,24]. Estrogen Receptor alpha
(ER- $\alpha$ ) regulates adipocytes activity and body fat distribution. It has been demonstrated by Davis et al. that the knockdown of adipocytespecific ER in adult mice led to an increase of the body weight, adipose tissue mass and adipocyte size in female subjects [25]. Alongside, adipokines that modulates fat mass, lipoprotein metabolism, size and number of adipocytes [26,27], are involved in the pathogenesis of hypertension, CVD and osteoporosis [28,29]. High levels of leptin and low levels of adiponectin are associated to insulin resistance in post-menopausal women [29].

The ECS is involved in modulating food intake, energy balance, thermogenesis and fat accumulation [9,30-34]. In particular, CB1 and $\mathrm{CB} 2$ receptors directly regulate lipid metabolism in adipose tissues $[9,32,33]$. CB1 expression levels are very high in obesity and its genetic ablation or its blockade with a selective antagonist determines a decrease in body weight and in food intake in mice $[9,35]$. In contrast, CB2 stimulation with its selective agonists induces a reduction in food intake and improves both body weight and obesity-associated inflammation in diet-induced obese mice. Its genetic ablation and its non-functional variant, Q63R, cause adiposity accumulation and eating disorders in humans $[9,35]$. Moreover, it has been demonstrated that CB2 stimulation with its selective agonist JWH-133 is able to reduce the obesity-related inflammatory state and to induce browning through the up regulation of the Uncoupling Protein 1 (UCP1). These findings suggest $\mathrm{CB} 2$ as a possible antiobesity pharmacological target [35]. Backhouse et al. demonstrated for the first time that the administration of rimonabant, an antagonist of CB1 receptor, for 12 weeks in obese Caucasian post-menopausal women promoted lipolysis and fatty acids oxidation, determining energy expenditure [36]. Several polymorphic variants of CB1 gene are associated to obesity, alteration in body fat distribution and metabolic disorders in men [37-39]. On this evidence Milewicz et al. demonstrated that $\mathrm{CB} 1$ gene variants influenced adiposity, fat distribution and metabolic disorders also in postmenopausal women; in detail, the $\mathrm{A} 3813 \mathrm{G}$ polymorphism was associated with higher body mass, BMI, waist circumference, total fat and fat percentage [37].

Obesity has an impact on the relationship between $\mathrm{CB} 2$ gene SNPs and Osteoporosis (OP) risk [40,41]. It has been demonstrated that the CB2 variant rs3003336 is associated to abdominal obesity in obese post-menopausal women which showed an increased risk of OP onset [30]. In addition, endocannabinoids are involved in obesity, regulating metabolism, body composition and energy homeostasis $[42,43]$. Indeed, it has been reported that Anandamide (AEA) and 2-Arachydonoil Glycerol (2-AG) levels were retrieved extremely high in both obese men and women [42,44,45], but with a higher concentration in women [32]. Engeli et al. demonstrated that AEA and 2-Arachydonoil 2-AG were present at very high level in obese post-menopausal women [43]. These increased levels were related to decreased levels and activity of FAAH, responsible for endocannabinoids degradation, in adipose tissue of obese women [43]. Taken together, these data highlight the important role of ECS in menopause-associated obesity; in particular, several variants of both cannabinoids receptors and endocannabinoids are involved in inducing metabolic disorders and obesity.

\section{Osteoporosis in Menopause: Role of Endocannabinoid System}

Osteopenia and Osteoporosis (OP) are experienced by 
postmenopausal women due to the interruption of gonad function [46,47]. Estrogen deficiency induces osteoclasts apoptosis, reducing the bone mass density and increasing bone fragility as well as the risk of fractures [48]. Osteoporotic fractures cause loss of mobility and several complications, deeply harming the quality of life of these women [49]. Hormone Replacement Therapy (HRT) is considered the first-line choice for the prevention and treatment of OP-related fractures in postmenopausal women at risk of fracture and younger than 60 years [50,51]. Conversely, standard HRT in women older than 60 years is not recommended due to the potential risk of long-term complications, including breast cancer, stroke and thromboembolic events [10,52-54]. Therefore, it is still necessary to develop strategies that allow the earlier identification of women at risk of fractures and to identify new therapeutic approaches for long-term OP prevention.

Both environmental and genetic factors contribute to the development and progression of OP [55,56]. Genome-wide association studies have reported the association between the CNR2 gene, which encodes the CB2 receptor, and OP susceptibility in different populations [57-60]. It is widely known that cannabinoids and their receptors, $\mathrm{CB} 1$ and $\mathrm{CB} 2$, play an important role in bone metabolism regulating bone cell function [10]. CB1 activation stimulates osteoclast activity, whereas CB2 activation inhibits osteoclast activity and promotes osteoblast function [61-64].

Woo et al. demonstrated that several SNPs (rs2501431 and rs3003336 polymorphisms) in CNR genes may be genetic factors affecting Bone Mineral Density (BMD) in a cohort of Korean postmenopausal women [58]. In agreement, Yamada et al indicated that CNR2 loci were associated with reduced bone mass in Japanese women [59]. Alongside, Karsak et al. demonstrated that polymorphisms in CNR2 affect CB2 expression and activity, suggesting that a reduced efficacy of $\mathrm{CB} 2$ signaling could result in a lower bone density and even OP [57]. Therefore, these studies suggest $\mathrm{CB} 2$ as a possible marker to identify women at risk of fractures. Moreover, several authors suggested also a role for the CB2 receptor in the etiology of OP providing a new therapeutic target for this common disease [65-67].

Rossi et al. demonstrated that in Osteoclasts (OCs) from ovariectomized mice, the estrogen deficiency is associated with a reduction in $\mathrm{CB} 2$ receptor expression and signaling [68]. In accordance with this finding, an estrogen receptor antagonist downregulates the expression of CB2 receptors in human OCs [69]. Conversely, confirming the anti-osteoporotic properties of estrogens, the 17- $\beta$-estradiol is able to induce an increase of CB2 expression through the recruitment of a putative estrogen-responsive element in the CB2 gene [70]. Rossi et al. also investigated the alteration of endocannabinoid system in OCs from postmenopausal women with or without $\mathrm{OP}$ demonstrated an alteration of $\mathrm{CB} 1$ and $\mathrm{CB} 2$ receptors expression as well as of endogenous mediator levels, responsible for the bone alteration [71]. Moreover, CB2 stimulation reduces the number of active OCs, confirming the protective role of the receptor in bone metabolism $[9,10,35]$. Interestingly, Raloxifene, a selective estrogen receptor modulator approved for the treatment of postmenopausal OP [72], is an inverse agonist for $\mathrm{CB} 2$, suggesting that the anti-osteoporotic activity of the drug it might be partially mediated through the CB2 $[73,74]$.
All these studies suggest the possibility of acting on CB2 receptor instead of adopting HRT to reduce bone resorption in postmenopausal OP.

\section{Cardiopathy and Oxidative Stress in Menopause: Role of Endocannabinoid System}

The correlation between endogenous estrogen levels and cardiovascular health is very strong and well documented in literature [75]. Over the last years several authors demonstrated that cardiovascular diseases (i.e. atherosclerosis, cardiac remodeling and hypertension) are less frequent in premenopausal women, in which estrogen levels are high, than in age-matched men and that this advantage decreases with the estrogen loss at the menopause onset [76,77]. Estrogen reduction is indeed related to many biochemical, functional and morphological alterations [78] such vascular inflammation and also increase in sympathetic tone and blood pressure $[79,80]$. Menopausal-related cardiovascular diseases as well as mortality in postmenopausal women affected by heart diseases are significantly reduced by the commonly administered HRT $[81,82]$, especially because of the increase in Nitric Oxide (NO) production, strongly related to a reduction in coronary resistance and peripheral vascular tone [83]. NO is produced by NO Synthase (NOS) starting from L-arginine and is involved in many physiological and pathological events, for example in inflammation, hyperalgesia and also several neurological disorders $[84,85]$.

The ECS is expressed in cardiovascular system and plays an important modulating role on contractility and vascular tone [86]. In literature it is reported that $\mathrm{N}$-Arachidonoyl Ethanolamine or Anandamide (AEA) causes an increase in NO levels with a consequent endothelium-dependent vasorelaxation [65] probably mediated by the $\mathrm{CB} 1$ receptor $[87,88]$. Among the known NOS isoforms, the Endothelial one (eNOS) is the most expressed in cardiovascular system and it plays an important antioxidant role, besides its function in vasorelaxation [89]. The exact mechanism by which endocannabinoids act as protective agents against cardiopathy in postmenopausal women is still unclear. However, it seems to be principally related to the activation of CB1 and CB2 receptors $[90,91]$. Szabó et al. after inducing estrogen deficiency in female rats by ovariectomy, observed a drastic reduction in $\mathrm{CB} 1$ receptor expression in their cardiac tissue [92]. This condition was restored after two-week treatment with AEA, obtaining the same benefits of canonic estrogen replacement therapy, maybe via NOS pathway. In according with this study, already in 2002 Joyeux et al. demonstrated that NOS inhibition effects were similar to CB2 receptor antagonism, while selective CB1 and CB2 agonists, respectively ACEA and JWH015, reduced the infarct size in the same manner of 2-Arachidonoylglycerol (2-AG), the endogenous agonist of the CB1 $[93,94]$. Consistently, in CB2 knockout mice or after CB2 antagonism it was observed a larger infarct size [95,96]. In 2014 also Wheal and collaborators described a correlation between cannabinoids, oxidative stress and cardiovascular risk, reporting that in Zucker obese rats the impairment in eNOSdependent relaxation of the femoral artery could be restored with the administration of cannabidiol, a non-specific activator of CB1 and CB2 receptors [97]. Moreover, in this year, Van Hove et al. performed a study on diabetic rats, founding that treatment with CB2 receptor 
agonist could elevate eNOS-related dilation of cerebral arterioles directly ameliorating tissue blood flow thus diminishing also vascular risk [98]. These evidences support the cardiovascular protective role of ECS components and the main hypothesis about the underlying mechanism is related to their capability to contain the inflammatory processes [8] and inhibit oxidative stress, that are frequently elevated in postmenopausal women [99].

\section{Cancer in Menopause: Role of Endocannabinoids System}

One of the most remarkable characteristic of menopause condition is the reduction in estrogen circulating levels [100], with a wide range of side effects that compromise life quality for postmenopausal women, to the point that hormone replacement therapy becomes necessary [101]. From literature it is well-known that high estrogen levels play a protective role [102] and represent a valid prognostic factor for different kind of cancers, including liver [103] and lung cancers $[91,93]$. Therefore, with menopause onset and the related estrogen decrease, cancer survival rate diminishes for women in comparison with age-matched men. The reasons underlying this disparity include not only sex hormone levels, but also sex distinctions in genetics and epigenetics [92], sex hormone receptors levels [104] and smoking history [105]. Considering this aspect, it is possible to recognize the beneficial effect of the HRT also in containing tumor development and progression [106].

Together with the reduction of estrogens, in postmenopausal women it has been also seen a decrease in AEA concentrations, similar to the luteal phase of premenopausal subjects [107]. Several authors reported the anti-cancer role of AEA, describing its capabilities to affect cell cycle distribution of gastric cancer cells $[15,108,109]$ and also to reduce proliferation of neuroblastoma, prostate carcinoma and melanoma cells [110-112]. Cancer cells are more sensitive to endocannabinoids compared to healthy cells, since a most abundant presence of EC receptors on their surface [113]. When properly stimulated, the ECS induces apoptosis, arrests cell cycle and inhibits metastasis $[114,115]$ in both animal models and cell lines of cancer. For example, the CB agonist WIN-55, 212-2 has been seen to increase in a significative manner the expression of both $\mathrm{CB} 1$ and $\mathrm{CB} 2$ receptors in human prostate cancer cells ( $\mathrm{LNCaP}$ ) with a strong reduction in their viability [116], as well as $\Delta 9$-Tetrahydrocannabinol (THC) [113]. All these evidences put the ECS in an interesting position as pharmacological target against cancer. Moreover, there is a well-documented interaction between this system and the sex steroid hormones $[117,118]$ that let hypothesize a particular impact on hormone-related neoplasms. Estrogens are strongly involved in regulation of cell proliferation and apoptosis [119], in particular the most abundant estrogen is $17 \beta$-Estradiol (E2) and it is able to directly stimulate the AEA release from endothelial cells and also to inhibit the synthesis of FAAH, the enzyme responsible for AEA degradation [120]. In colorectal carcinoma as well as in normal colonic epithelium E2 regulates CB1 expression [121]. Consequently, the collapse of estrogens with menopause causes reduction in AEA levels and a minor stimulation of $\mathrm{CB}$ receptors, thus reducing the protective effects of EC system and exposing postmenopausal women to a higher risk for cancer development. On the other hand, progesterone has been found upregulating FAAH activity, thus decreasing AEA plasma levels [122]. Theoretically, this could be one of the reasons why HRT is, in long term, considered responsible for the major susceptibility in developing some subtype of cancers, such as endometrial carcinoma [123].

\section{Conclusion}

Menopause-related diseases reduce quality of life and could represent an important public and economic health burden in nowadays society. It is well known that $\mathrm{CB} 1$ and $\mathrm{CB} 2$ receptors play specifically roles in regulating several physiological functions.

In this review we highlighted the possible link between ECS system, estrogens deficiency and the development of several paraphysiologic and pathological changes related to menopausal transition, including obesity, osteoporosis, cardiovascular diseases and increased risk of cancer. The compromised hormone condition in postmenopausal women could induce an alteration of cannabinoid receptors expression and endocannabinoids levels and, consequentially, a reduced efficacy of receptor signaling. This alteration might be related to increased inflammation triggering, lowered bone density, increased oxidative stress, cardiovascular risk, and cancer progression.

Reported studies suggest a protective role of the ECS in counteract the harmful effects of these menopause-related diseases, suggesting it as a good and alternative prognostic marker and therapeutic target to address further researches.

\section{References}

1. Nelson HD. Menopause. Lancet. 2008; 371: 760-770.

2. Velez MP, Alvarado BE, Rosendaal N, da Camara SM, Belanger E, Richardson $\mathrm{H}$, et al. Age at natural menopause and physical functioning in postmenopausal women: the Canadian Longitudinal Study on Aging. Menopause (New York, NY). 2019; 26: 958-965.

3. Yao M, Liu H, Li B, Liu Y, Mu Y. The Relationship between Earlier Onset of Natural Menopause and Elevated Urinary Albumin-Creatinine Ratio in Postmenopausal Chinese Women. Diabetes Metab Syndr Obes. 2021; 14: 847-856.

4. Riemma G, Schiattarella A, La Verde M, Zarobbi G, Garzon S, Cucinella $\mathrm{G}$, et al. Efficacy of Low-Dose Paroxetine for the Treatment of Hot Flushes in Surgical and Physiological Postmenopausal Women: Systematic Review and Meta-Analysis of Randomized Trials. Medicina (Kaunas). 2019; 55: 554.

5. De Franciscis P, Conte A, Schiattarella A, Riemma G, Cobellis L, Colacurci N. Non-hormonal Treatments For Menopausal Symptoms and Sleep Disturbances: A Comparison Between Purified Pollen Extracts and Soy Isoflavones. Curr Pharm Des. 2020; 26: 4509-4514.

6. Day FR, Ruth KS, Thompson DJ, Lunetta KL, Pervjakova N, Chasman DI, et al. Large-scale genomic analyses link reproductive aging to hypothalamic signaling, breast cancer susceptibility and BRCA1-mediated DNA repair. Nat Genet. 2015; 47: 1294-1303.

7. Di Marzo V, Piscitelli F. The Endocannabinoid System and its Modulation by Phytocannabinoids. Neurotherapeutics. 2015; 12: 692-698.

8. Argenziano M, Tortora C, Bellini G, Di Paola A, Punzo F, Rossi F. The Endocannabinoid System in Pediatric Inflammatory and Immune Diseases. Int J Mol Sci. 2019; 20.

9. Rossi F, Punzo F, Umano GR, Argenziano M, Miraglia Del Giudice E. Role of Cannabinoids in Obesity. Int J Mol Sci. 2018; 19: 2690.

10. Rossi F, Tortora C, Punzo F, Bellini G, Argenziano M, Di Paola A, et al. The Endocannabinoid/Endovanilloid System in Bone: From Osteoporosis to Osteosarcoma. Int J Mol Sci. 2019; 20: 1919.

11. Sierra S, Luquin N, Navarro-Otano J. The endocannabinoid system in 
cardiovascular function: novel insights and clinical implications. Clin Auton Res. 2018; 28: 35-52.

12. Moreno E, Cavic M, Krivokuca A, Casado V, Canela E. The Endocannabinoid System as a Target in Cancer Diseases: Are We There Yet? Fron Pharmacol. 2019; 10: 339.

13. Karasu T, Marczylo TH, Maccarrone M, Konje JC. The role of sex steroid hormones, cytokines and the endocannabinoid system in female fertility. Hum Reprod Update. 2011; 17: 347-361.

14. Torrens JI, Sutton-Tyrrell K, Zhao X, Matthews K, Brockwell S, Sowers M et al. Relative androgen excess during the menopausal transition predicts incident metabolic syndrome in midlife women: study of Women's Health across the Nation. Menopause. 2009; 16: 257-264.

15. Ko SH, Kim HS. Menopause-Associated Lipid Metabolic Disorders and Foods Beneficial for Postmenopausal Women. Nutrients. 2020; 12: 202

16. Marchand GB, Carreau AM, Weisnagel SJ, Bergeron J, Labrie F, Lemieux $\mathrm{S}$, et al. Increased body fat mass explains the positive association between circulating estradiol and insulin resistance in postmenopausal women. Am J Physiol Endocrinol Metab. 2018; 314: E448-E456

17. Razmjou S, Abdulnour J, Bastard JP, Fellahi S, Doucet E, Brochu M, et al. Body composition, cardiometabolic risk factors, physical activity, and inflammatory markers in premenopausal women after a 10-year follow-up: a MONET study. Menopause. 2018; 25: 89-97.

18. Janssen I, Powell LH, Kazlauskaite R, Dugan SA. Testosterone and viscera fat in midlife women: the Study of Women's Health across the Nation (SWAN) fat patterning study. Obesity (Silver Spring). 2010; 18: 604-610.

19. Stefanska A, Bergmann K, Sypniewska G. Metabolic Syndrome and Menopause: Pathophysiology, Clinical and Diagnostic Significance. Adv Clin Chem. 2015; 72: 1-75

20. Dmitruk A, Czeczelewski J, Czeczelewska E, Golach J, Parnicka U. Body composition and fatty tissue distribution in women with various menstrual status. Rocz Panstw Zakl Hig. 2018; 69: 95-101.

21. Lazzer S, Bedogni G, Lafortuna CL, Marazzi N, Busti C, Galli R, et al Relationship between basal metabolic rate, gender, age, and body composition in 8,780 white obese subjects. Obesity (Silver Spring). 2010; 18: $71-78$

22. Rhee Y, Paik MJ, Kim KR, Ko YG, Kang ES, Cha BS, et al. Plasma free fatty acid level patterns according to cardiovascular risk status in postmenopausal women. Clin Chim Acta. 2008; 392: 11-16.

23. Zago V, Sanguinetti S, Brites F, Berg G, Verona J, Basilio F, et al. Impaired high density lipoprotein antioxidant activity in healthy postmenopausa women. Atherosclerosis. 2004; 177: 203-210.

24. Anagnostis P, Stevenson JC, Crook D, Johnston DG, Godsland IF. Effects of menopause, gender and age on lipids and high-density lipoprotein cholesterol subfractions. Maturitas. 2015; 81: 62-68.

25. Davis KE, M DN, Sun K, W MS, J DB, J AZ, et al. The sexually dimorphic role of adipose and adipocyte estrogen receptors in modulating adipose tissue expansion, inflammation, and fibrosis. Mol Metab. 2013; 2: 227-242.

26. Waki $\mathrm{H}$, Tontonoz P. Endocrine functions of adipose tissue. Annu Rev Pathol. 2007; 2: 31-56.

27. Reaven G, Abbasi F, McLaughlin T. Obesity, insulin resistance, and cardiovascular disease. Recent Prog Horm Res. 2004; 59: 207-223.

28. Azizieh FY, Shehab D, Al Jarallah K, Mojiminiyi O, Gupta R, Raghupathy R. Circulatory pattern of cytokines, adipokines and bone markers in postmenopausal women with low BMD. J Inflamm Res. 2019; 12: 99-108.

29. Matsuzawa Y. Therapy Insight: adipocytokines in metabolic syndrome and related cardiovascular disease. Nat Clin Pract Cardiovasc Med. 2006; 3: 3542.

30. Izzo AA, Piscitelli F, Capasso R, Aviello G, Romano B, Borrelli F, et al. Peripheral endocannabinoid dysregulation in obesity: relation to intestinal motility and energy processing induced by food deprivation and re-feeding. Br J Pharmacol. 2009; 158: 451-461.
31. Richey JM, Woolcott O. Re-visiting the Endocannabinoid System and Its Therapeutic Potential in Obesity and Associated Diseases. Curr Diab Rep. 2017; 17: 99.

32. Di Marzo V, Goparaju SK, Wang L, Liu J, Batkai S, Jarai Z, et al. Leptinregulated endocannabinoids are involved in maintaining food intake. Nature. 2001; 410: 822-825.

33. Cota D, Marsicano G, Tschop M, Grubler Y, Flachskamm C, Schubert M, et al. The endogenous cannabinoid system affects energy balance via central orexigenic drive and peripheral lipogenesis. J Clin Invest. 2003; 112: 423431.

34. Khan N, Halim SA, Khan W, Zafar SK, Ul-Haq Z. In-silico designing and characterization of binding modes of two novel inhibitors for CB1 receptor against obesity by classical 3D-QSAR approach. J Mol Graph Model. 2019; 89: 199-214

35. Rossi F, Bellini G, Luongo L, Manzo I, Tolone S, Tortora C, et al. Cannabinoid Receptor 2 as Antiobesity Target: Inflammation, Fat Storage, and Browning Modulation. J Clin Endocrinol Metab. 2016; 101: 3469-3478.

36. Backhouse K, Sarac I, Shojaee-Moradie F, Stolinski M, Robertson MD, Frost GS, et al. Fatty acid flux and oxidation are increased by rimonabant in obese women. Metabolism. 2012; 61: 1220-1223.

37. Milewicz A, Tworowska-Bardzinska $U$, Jedrzejuk D, Lwow F, Dunajska K Laczmanski L, et al. Are endocannabinoid type 1 receptor gene (CNR1) polymorphisms associated with obesity and metabolic syndrome in postmenopausal Polish women? Int J Obes (Lond). 2011; 35: 373-377.

38. Russo P, Strazzullo P, Cappuccio FP, Tregouet DA, Lauria F, Loguercio $M$, et al. Genetic variations at the endocannabinoid type 1 receptor gene (CNR1) are associated with obesity phenotypes in men. J Clin Endocrino Metab. 2007; 92: 2382-2386.

39. Benzinou M, Chevre JC, Ward KJ, Lecoeur C, Dina C, Lobbens S, et al. Endocannabinoid receptor 1 gene variations increase risk for obesity and modulate body mass index in European populations. Hum Mol Genet. 2008; 17: 1916-1921.

40. Zheng W, Liu C, Lei M, Han Y, Zhou X, Li C, et al. Evaluation of common variants in the CNR2 gene and its interaction with abdominal obesity for osteoporosis susceptibility in Chinese post-menopausal females. Bone Joint Res. 2019; 8: 544-549.

41. Neglia C, Argentiero A, Chitano G, Agnello N, Ciccarese R, Vigilanza A, et al. Diabetes and Obesity as Independent Risk Factors for Osteoporosis: Updated Results from the ROIS/EMEROS Registry in a Population of Five Thousand Post-Menopausal Women Living in a Region Characterized by Heavy Environmental Pressure. Int J Environ Res Public Health. 2016; 13: 1067.

42. Haidari $F$, Aghamohammadi $V$, Mohammadshahi $M$, Ahmadi-Angali $K$ Asghari-Jafarabadi $M$. Whey protein supplementation reducing fasting levels of anandamide and 2-AG without weight loss in pre-menopausal women with obesity on a weight-loss diet. Trials. 2020; 21: 657.

43. Engeli S, Bohnke J, Feldpausch M, Gorzelniak K, Janke J, Batkai S, et al Activation of the peripheral endocannabinoid system in human obesity. Diabetes. 2005; 54: 2838-2843.

44. Bennetzen MF, Wellner N, Ahmed SS, Ahmed SM, Diep TA, Hansen $\mathrm{HS}$, et al. Investigations of the human endocannabinoid system in two subcutaneous adipose tissue depots in lean subjects and in obese subjects before and after weight loss. Int J Obes (Lond). 2011; 35: 1377-1384.

45. Jones PJ, Lin L, Gillingham LG, Yang H, Omar JM. Modulation of plasma $\mathrm{N}$-acylethanolamine levels and physiological parameters by dietary fatty acid composition in humans. J Lipid Res. 2014; 55: 2655-2664.

46. De Franciscis P, Colacurci N, Riemma G, Conte A, Pittana E, Guida M, et al A Nutraceutical Approach to Menopausal Complaints. Medicina (Kaunas). 2019; 55: 544

47. Minkin MJ. Menopause: Hormones, Lifestyle, and Optimizing Aging. Obstet Gynecol Clin North Am. 2019; 46: 501-514.

48. Gurban CV, Balas MO, Vlad MM, Caraba AE, Jianu AM, Bernad ES, et 
al. Bone turnover markers in postmenopausal osteoporosis and thei correlation with bone mineral density and menopause duration. Rom J Morphol Embryol. 2019; 60: 1127-1135.

49. Idris Al, van 't Hof RJ, Greig IR, Ridge SA, Baker D, Ross RA, et al Regulation of bone mass, bone loss and osteoclast activity by cannabinoid receptors. Nat Med. 2005; 11: 774-779.

50. Gatti D, Fassio A. Pharmacological management of osteoporosis in postmenopausal women: The current state of the art. J Popul Ther Clin Pharmacol. 2019; 26: e1-e17.

51. Mainini G, Rotondi M, Di Nola K, Pezzella MT, lervolino SA, Seguino E, et al. Oral supplementation with antioxidant agents containing alpha lipoic acid: effects on postmenopausal bone mass. Clin Exp Obstet Gynecol. 2012; 39: 489-493.

52. Paciuc J. Hormone Therapy in Menopause. Adv Exp Med Biol. 2020; 1242 89-120.

53. Lobo RA. Hormone-replacement therapy: current thinking. Nat Rev Endocrinol. 2017; 13: 220-231.

54. de Villiers TJ, Pines A, Panay N, Gambacciani M, Archer DF, Baber RJ, et al. Updated 2013 International Menopause Society recommendations on menopausal hormone therapy and preventive strategies for midlife health. Climacteric. 2013; 16: 316-337.

55. Ozbas H, Tutgun Onrat S, Ozdamar K. Genetic and environmental factors in human osteoporosis. Mol Biol Rep. 2012; 39: 11289-11296.

56. Carrasquer A, Nebane NM, Williams WM, Song ZH. Functional consequences of nonsynonymous single nucleotide polymorphisms in the CB2 cannabinoid receptor. Pharmacogenet Genomics. 2010; 20: 157-166.

57. Karsak M, Cohen-Solal M, Freudenberg J, Ostertag A, Morieux C, Kornak $\mathrm{U}$, et al. Cannabinoid receptor type 2 gene is associated with human osteoporosis. Hum Mol Genet. 2005; 14: 3389-3396.

58. Woo JH, Kim H, Kim JH, Kim JG. Cannabinoid receptor gene polymorphisms and bone mineral density in Korean postmenopausal women. Menopause. 2015; 22: 512-519.

59. Yamada Y, Ando F, Shimokata H. Association of candidate gene polymorphisms with bone mineral density in community-dwelling Japanese women and men. Int J Mol Med. 2007; 19: 791-801.

60. Zhang C, Ma J, Chen G, Fu D, Li L, Li M. Evaluation of common variants in CNR2 gene for bone mineral density and osteoporosis susceptibility in postmenopausal women of Han Chinese. Osteoporos Int. 2015; 26: 2803 2810 .

61. Ofek O, Karsak M, Leclerc N, Fogel M, Frenkel B, Wright K, et al. Peripheral cannabinoid receptor, CB2, regulates bone mass. Proc Natl Acad Sci. USA 2006; 103: 696-701.

62. Idris Al, Sophocleous A, Landao-Bassonga E, Canals M, Milligan G, Baker D et al. Cannabinoid receptor type 1 protects against age-related osteoporosis by regulating osteoblast and adipocyte differentiation in marrow stromal cells. Cell Metab. 2009; 10: 139-147.

63. Rossi F, Siniscalco D, Luongo L, De Petrocellis L, Bellini G, Petrosino S, et al. The endovanilloid/endocannabinoid system in human osteoclasts: possible involvement in bone formation and resorption. Bone. 2009; 44 476-484.

64. Rossi F, Bellini G, Tortora C, Bernardo ME, Luongo L, Conforti A, et al. CB2 and TRPV1 receptors oppositely modulate in vitro human osteoblast activity. Pharmacological Research. 2015; 99: 194-201.

65. Idris Al, Sophocleous A, Landao-Bassonga E, van't Hof RJ, Ralston SH. Regulation of bone mass, osteoclast function, and ovariectomy-induced bone loss by the type 2 cannabinoid receptor. Endocrinology. 2008; 149 : 5619-5626.

66. Bab I, Ofek O, Tam J, Rehnelt J, Zimmer A. Endocannabinoids and the regulation of bone metabolism. J Neuroendocrinol. 2008; 20: 69-74.

67. Bab I, Zimmer A, Melamed E. Cannabinoids and the skeleton: from marijuana to reversal of bone loss. Ann Med. 2009; 41: 560-567.
68. Rossi F, Bellini G, Torella M, Tortora C, Manzo I, Giordano C, et al. The genetic ablation or pharmacological inhibition of TRPV1 signalling is beneficial for the restoration of quiescent osteoclast activity in ovariectomized mice. Brit J Pharmacol. 2014; 171: 2621-2630.

69. Guida M, Ligresti A, De Filippis D, D'Amico A, Petrosino S, Cipriano $M$, et al. The levels of the endocannabinoid receptor CB2 and its ligand 2-arachidonoylglycerol are elevated in endometrial carcinoma. Endocrinology. 2010; 151: 921-928.

70. Rossi F, Bellini G, Luongo L, Mancusi S, Torella M, Tortora C, et al. The 17-beta-oestradiol inhibits osteoclast activity by increasing the cannabinoid CB2 receptor expression. Pharmacol Res. 2013; 68: 7-15.

71. Rossi F, Bellini G, Luongo L, Torella M, Mancusi S, De Petrocellis L, et al. The endovanilloid/endocannabinoid system: a new potential target for osteoporosis therapy. Bone. 2011; 48: 997-1007.

72. Colacurci N, Fornaro F, Cobellis L, De Franciscis $P$, Torella M, Sepe E, et al. Raloxifene slows down the progression of intima-media thickness in postmenopausal women. Menopause. 2007; 14: 879-884.

73. Muchmore DB. Raloxifene: A selective estrogen receptor modulator (SERM) with multiple target system effects. Oncologist. 2000; 5: 388-392.

74. Kumar $\mathrm{P}$, Song $\mathrm{ZH}$. Identification of raloxifene as a novel CB2 inverse agonist. Biochem Biophys Res Commun. 2013; 435: 76-81.

75. Zhao D, Guallar E, Ouyang P, Subramanya V, Vaidya D, Ndumele CE, et al Endogenous Sex Hormones and Incident Cardiovascular Disease in PostMenopausal Women. J Am Coll Cardiol. 2018; 71: 2555-2566.

76. Posa A, Kupai K, Menesi R, Szalai Z, Szabo R, Pinter Z, et al. Sexua dimorphism of cardiovascular ischemia susceptibility is mediated by heme oxygenase. Oxid Med Cell Longev. 2013; 2013: 521563.

77. Mascarenhas-Melo F, Sereno J, Teixeira-Lemos E, Ribeiro S, RochaPereira $P$, Cotterill E, et al. Markers of increased cardiovascular risk in postmenopausal women: focus on oxidized-LDL and HDL subpopulations. Dis Markers. 2013; 35: 85-96.

78. Rosano GM, Vitale C, Marazzi G, Volterrani M. Menopause and cardiovascular disease: the evidence. Climacteric. 2007; 10: 19-24.

79. Novella S, Heras M, Hermenegildo C, Dantas AP. Effects of estrogen on vascular inflammation: a matter of timing. Arterioscler Thromb Vasc Biol. 2012; 32: 2035-2042.

80. Moreau KL, Hildreth KL, Meditz AL, Deane KD, Kohrt WM. Endothelia function is impaired across the stages of the menopause transition in healthy women. J Clin Endocrinol Metab. 2012; 97: 4692-4700.

81. Kalantaridou SN, Naka KK, Papanikolaou E, Kazakos N, Kravariti M, Calis $\mathrm{KA}$, et al. Impaired endothelial function in young women with premature ovarian failure: normalization with hormone therapy. J Clin Endocrino Metab. 2004; 89: 3907-3913

82. Posa A, Szabo R, Kupai K, Berko AM, Veszelka M, Szucs G, et al Cardioprotective Effect of Selective Estrogen Receptor Modulator Raloxifene Are Mediated by Heme Oxygenase in Estrogen-Deficient Rat. Oxid Med Cell Longev. 2017; 2017: 2176749.

83. Schierbeck LL, Rejnmark L, Tofteng CL, Stilgren L, Eiken P, Mosekilde L, et al. Effect of hormone replacement therapy on cardiovascular events in recently postmenopausal women: randomised trial. BMJ. 2012; 345: e6409.

84. Zhang N, Diao Y, Hua R, Wang J, Han S, Li J, et al. Nitric oxide-mediated pathways and its role in the degenerative diseases. Front Biosci (Landmark Ed). 2017; 22: 824-834.

85. Duncan AJ, Heales SJ. Nitric oxide and neurological disorders. Mol Aspects Med. 2005; 26: 67-96.

86. O'Sullivan SE. Endocannabinoids and the Cardiovascular System in Health and Disease. Handb Exp Pharmacol. 2015; 231: 393-422.

87. Gercek OZ, Oflaz B, Oguz N, Demirci K, Gunduz O, Ulugol A. Role of Nitric Oxide in the Antipruritic Effect of WIN 55,212-2, a Cannabinoid Agonist. Basic Clin Neurosci. 2020; 11: 473-480. 
88. Prevot V, Rialas CM, Croix D, Salzet M, Dupouy JP, Poulain $P$, et al Morphine and anandamide coupling to nitric oxide stimulates $\mathrm{GnRH}$ and CRF release from rat median eminence: neurovascular regulation. Brain Res. 1998; 790: 236-244.

89. Daiber A, Xia N, Steven S, Oelze M, Hanf A, Kroller-Schon S, et al. New Therapeutic Implications of Endothelial Nitric Oxide Synthase (eNOS) Function/Dysfunction in Cardiovascular Disease. Int J Mol Sci. 2019; 20 187.

90. Tuma RF, Steffens S. Targeting the endocannabinod system to limit myocardial and cerebral ischemic and reperfusion injury. Curr Pharm Biotechnol. 2012; 13: 46-58.

91. Pacher P, Mukhopadhyay P, Mohanraj R, Godlewski G, Batkai S, Kunos G. Modulation of the endocannabinoid system in cardiovascular disease: therapeutic potential and limitations. Hypertension. 2008; 52: 601-607.

92. Szabo R, Borzsei D, Szabo Z, Hoffmann A, Zupko I, Priksz D, et al. A Potential Involvement of Anandamide in the Modulation of $\mathrm{HO} / \mathrm{NOS}$ Systems: Women, Menopause, and "Medical Cannabinoids". Int J Mol Sci. 2020; 21: 8801

93. Joyeux M, Arnaud C, Godin-Ribuot D, Demenge P, Lamontagne D, Ribuot C. Endocannabinoids are implicated in the infarct size-reducing effect conferred by heat stress preconditioning in isolated rat hearts. Cardiovasc Res. 2002; 55: 619-625.

94. Schmid PC, Schwartz KD, Smith CN, Krebsbach RJ, Berdyshev EV, Schmid $\mathrm{HH}$. A sensitive endocannabinoid assay. The simultaneous analysis of $\mathrm{N}$-acylethanolamines and 2-monoacylglycerols. Chem Phys Lipids. 2000; 104: 185-191.

95. Zhang M, Martin BR, Adler MW, Razdan RK, Ganea D, Tuma RF. Modulation of the balance between cannabinoid $\mathrm{CB}(1)$ and $\mathrm{CB}(2)$ receptor activation during cerebral ischemic/reperfusion injury. Neuroscience. 2008; 152: 753760.

96. Zhang M, Adler MW, Abood ME, Ganea D, Jallo J, Tuma RF. CB2 recepto activation attenuates microcirculatory dysfunction during cerebral ischemic/ reperfusion injury. Microvasc Res. 2009; 78: 86-94.

97. Wheal AJ, Cipriano M, Fowler CJ, Randall MD, O'Sullivan SE. Cannabidio improves vasorelaxation in Zucker diabetic fatty rats through cyclooxygenase activation. J Pharmacol Exp Ther. 2014; 351: 457-466.

98. Van Hove L, Kim KR, Arrick DM, Mayhan WG. A cannabinoid type 2 (CB2) receptor agonist augments NOS-dependent responses of cerebral arterioles during type 1 diabetes. Microvasc Res. 2021; 133: 104077.

99. Giacoppo S, Gugliandolo A, Trubiani O, Pollastro F, Grassi G, Bramanti P, et al. Cannabinoid CB2 receptors are involved in the protection of RAW264.7 macrophages against the oxidative stress: an in vitro study. Eur J Histochem. 2017; 61: 2749

100.Zhong GC, Liu Y, Chen N, Hao FB, Wang K, Cheng JH, et al. Reproductive factors, menopausal hormone therapies and primary liver cancer risk: a systematic review and dose-response meta-analysis of observational studies. Hum Reprod Update. 2016; 23: 126-138.

101. Yeh SH, Chen PJ. Gender disparity of hepatocellular carcinoma: the roles of sex hormones. Oncology. 2010; 78: 172-179.

102. Xu H, Wei Y, Zhang Y, Xu Y, Li F, Liu J, et al. Oestrogen attenuates tumour progression in hepatocellular carcinoma. J Pathol. 2012; 228: 216-229.

103. Wang R, Liu Y, Sun H, Wang T, Li C, Fan J, et al. Estradiol is significantly associated with prognosis in non-surgical liver cancer patients: from bench to bedside. Aging (Albany NY). 2021; 13: 3483-3500.

104.Skov BG, Fischer BM, Pappot H. Oestrogen receptor beta over expression in males with non-small cell lung cancer is associated with better survival. Lung Cancer. 2008; 59: 88-94.

105. Mollerup S, Berge G, Baera R, Skaug V, Hewer A, Phillips DH, et al. Sex differences in risk of lung cancer: Expression of genes in the $\mathrm{PAH}$ bioactivation pathway in relation to smoking and bulky DNA adducts. Int J Cancer. 2006; 119: 741-744.

106. Mukherjee TK, Malik $\mathrm{P}$, Hoidal JR. The emerging role of estrogen related receptoralpha in complications of non-small cell lung cancers. Oncol Lett. 2021; $21: 258$

107. Lam PM, Marczylo TH, El-Talatini M, Finney M, Nallendran V, Taylor AH et al. Ultra performance liquid chromatography tandem mass spectrometry method for the measurement of anandamide in human plasma. Anal Biochem. 2008; 380: 195-201.

108.Dong W, Liu Y, Zhu W, Mou Q, Wang J, Hu Y. Simulation of Swanson's literature-based discovery: anandamide treatment inhibits growth of gastric cancer cells in vitro and in silico. PLoS One. 2014; 9: e100436.

109. Miyato H, Kitayama J, Yamashita H, Souma D, Asakage M, Yamada J, et al. Pharmacological synergism between cannabinoids and paclitaxel in gastric cancer cell lines. J Surg Res. 2009; 155: 40-47.

110. Hamtiaux L, Hansoulle L, Dauguet N, Muccioli GG, Gallez B, Lambert DM Increasing antiproliferative properties of endocannabinoids in N1E-115 neuroblastoma cells through inhibition of their metabolism. PLoS One. 2011; 6: e26823.

111. Nithipatikom K, Gomez-Granados AD, Tang AT, Pfeiffer AW, Williams CL, Campbell WB. Cannabinoid receptor type 1 (CB1) activation inhibits small GTPase RhoA activity and regulates motility of prostate carcinoma cells. Endocrinology. 2012; 153: 29-41.

112. Hamtiaux L, Masquelier J, Muccioli GG, Bouzin C, Feron O, Gallez B, et al. The association of $\mathrm{N}$-palmitoylethanolamine with the FAAH inhibitor URB597 impairs melanoma growth through a supra-additive action. BMC Cancer. 2012; 12: 92.

113. McAllister SD, Chan C, Taft RJ, Luu T, Abood ME, Moore DH, et al. Cannabinoids selectively inhibit proliferation and induce death of cultured human glioblastoma multiforme cells. J Neurooncol. 2005; 74: 31-40.

114. Casanova ML, Blazquez C, Martinez-Palacio J, Villanueva C, FernandezAcenero $\mathrm{MJ}$, Huffman JW, et al. Inhibition of skin tumor growth and angiogenesis in vivo by activation of cannabinoid receptors. J Clin Invest. 2003; 111: 43-50.

115. Portella G, Laezza C, Laccetti P, De Petrocellis L, Di Marzo V, Bifulco M. Inhibitory effects of cannabinoid CB1 receptor stimulation on tumor growth and metastatic spreading: actions on signals involved in angiogenesis and metastasis. FASEB J. 2003; 17: 1771-1773

116. Sarfaraz S, Afaq F, Adhami VM, Mukhtar H. Cannabinoid receptor as a nove target for the treatment of prostate cancer. Cancer Res. 2005; 65: 16351641.

117. Notarnicola M, Messa C, Orlando A, Bifulco M, Laezza C, Gazzerro P, et al Estrogenic induction of cannabinoid $\mathrm{CB} 1$ receptor in human colon cancer cell lines. Scand J Gastroenterol. 2008; 43: 66-72.

118. Ayakannu T, Taylor AH, Marczylo TH, Willets JM, Konje JC. The endocannabinoid system and sex steroid hormone-dependent cancers. Int J Endocrinol. 2013; 2013: 259676.

119. Shrivastava A, Kuzontkoski PM, Groopman JE, Prasad A. Cannabidiol induces programmed cell death in breast cancer cells by coordinating the cross-talk between apoptosis and autophagy. Mol Cancer Ther. 2011; 10 : 1161-1172.

120. Maccarrone M, Bari M, Battista N, Finazzi-Agro A. Estrogen stimulates arachidonoylethanolamide release from human endothelial cells and platelet activation. Blood. 2002; 100: 4040-4048.

121. Gonzalez S, Mauriello-Romanazzi G, Berrendero F, Ramos JA, Franzoni MF, Fernandez-Ruiz J. Decreased cannabinoid CB1 receptor mRNA levels and immunoreactivity in pituitary hyperplasia induced by prolonged exposure to estrogens. Pituitary. 2000; 3: 221-226.

122. Maccarrone $M$, Valensise $H$, Bari $M$, Lazzarin $N$, Romanini $C$, FinazziAgro A. Progesterone up-regulates anandamide hydrolase in human Iymphocytes: role of cytokines and implications for fertility. J Immunol. 2001; 166: 7183-7189.

123. Dossus L, Allen N, Kaaks R, Bakken K, Lund E, Tjonneland A, et al. Reproductive risk factors and endometrial cancer: the European Prospective Investigation into Cancer and Nutrition. Int J Cancer. 2010; 127: 442-451. 